\title{
EFFECTS OF LEAD ON HAEM BIOSYNTHESIS DURING ERYTHROID DIFFERENTIATION IN VITRO
}

\author{
W. W. Ku, D. Slowiejko, L. L. Bestervelt, M. R. Buroker and W. N. Piper* \\ *Toxicology Program. School of Public Health, and Department of Pharmacology, Medical School, \\ University of Michigan, Ann Arbor, MI 48109, USA
}

(Received 26 September 1989; revisions received 16 February 1990)

\begin{abstract}
Murine erythroleukaemia cells (MELC) are erythroid precursor cells that undergo erythroid differentiation in the presence of the inducer hexamethylene bisacetamide (HMBA). The effects of lead on haem biosynthesis in MELC following HMBA-induced differentiation were studied. MELC were induced with $\mathrm{HMBA}$ in the presence of 20,40 and $80 \mu \mathrm{m}$-lead acetate and cell density, haem content, incorporation of ${ }^{14} \mathrm{C}$-labelled $\delta$-aminolaevulinic acid (ALA) into haem, and the activities of the enzymes $\delta$-aminolaevulinic acid dehydratase (ALA-D), uroporphyrinogen I synthetase (URO-S) and ferrochelatase (FERRO) were determined. MELC exposed to $80 \mu \mathrm{M}$-lead showed significant erythroid hypoplasia $(40-50 \%)$ and a significant decrease $(30-50 \%)$ in haem content at 2,4 and 6 days after induction in comparison with the controls. Significant inhibition of ALA-D, the most sensitive index, was noted at $20 \mu \mathrm{M}$-lead, and at $80 \mu \mathrm{M}$-lead ALA-D activity was decreased by $60-80 \%$ in comparison with the controls. URO-S and FERRO showed significant decreases of $34 \%$ and $50 \%$, respectively, at $80 \mu \mathrm{M}$-lead. A decrease of $50 \%$ in the incorporation of $\left[{ }^{14} \mathrm{C}\right] \mathrm{ALA}$ into haem at $80 \mu \mathrm{M}$-lead indicated an impairment in haem synthesis. The results suggest that the impairment of haem formation by lead is coincident with the production of severe erythroid hypoplasia.
\end{abstract}

\section{INTRODLCTION}

Lead has long been known to exert toxic effects on the erythropoietic system that are associated with the development of anaemia. There is little information available concerning the regulation of haem biosynthesis in the bone marrow associated with the development of anaemia following exposure to lead. Most previous studies concerning the aetiology of drug/toxicant-associated anaemia and its relationship to the biosynthesis of haem have been conducted with the mature red blood cell, which is not actively engaged in haem synthesis. Therefore, more relevant information is likely to be obtained by focusing study on the bone marrow rather than the red blood cell. Furthermore, controlled study of the role of various physiological (hormonal, nutritional) factors that regulate haem synthesis and/or influence the development of lead- or drug-associated anaemias is lacking. It is known that lead is preferentially deposited in bone marrow, and its concentration may reach 50 times that in blood (Albahary, 1972). Consequently, bone marrow cells, particularly premature crythroid precursor cells, are most susceptible to the toxic effects of lead which can result in an anaemia characterized by erythroid hypoplasia (Sassa, 1978).

\footnotetext{
* To whom correspondence should be addressed.

Abbreviations: $\mathrm{ALA}=\dot{\delta}$-aminolaevulinic acid; $\mathrm{ALA}-\mathrm{D}=$ $\delta$-aminolaevulinic acid dehydratase; $\mathrm{BPb}=$ blood lead concentration; DTT $=$ dithiothreitol; $F E R R=$ ferrochelatase: $\quad H M B A=$ hexamethylene bisacetamide: MELC = murine erythroleukaemia cells: $\mathrm{MEM}=$ minimum essential medium; $P B G=$ porphobilinogen; PBGase $=$ porphobilinogen deaminase; $\quad$ PBS $=$ phos phate buffered saline: URO-S = uroporphyrinogen I synthetase.
}

The haem biosynthetic pathway in erythroid tissue is a well known target for the toxic effects of lead (Bottomley and Muller-Eberhard, 1988). Lead has been shown to inhibit virtually all the enzymes of the pathway. $\delta$-Aminolaevulinic acid dehydratase (ALA-D) is most sensitive to lead in vitro and in vivo, followed by ferrochelatase (FERRO), coproporphyrinogen oxidase and porphobilinogen deaminase (PBGase, uroporphyrinogen I synthetase), respectively. Very high lead concentrations inhibit uroporphyrinogen decarboxylase and $\delta$-aminolaevulinic acid synthase (Bottomley, 1977).

As a result of the complex cellular heterogeneity of bone marrow in vivo, controlled study of this cellular target in the whole animal is rather difficult. Therefore, an in vitro system was used to study lead interactions and regulation of haem synthesis in erythroid precursor cells. The relative ease with which conditions can be manipulated in vitro makes it possible to study the role of various hormonal and nutritional factors that may regulate haem synthesis and /or influence the development of lead- or drug. associated anaemias.

Murine erythroleukaemia cells (MELC) are a continuous cell line of erythroid precursor celis which, in the presence of certain chemicals such as dimethylsulphoxide and hexamethylene bisacetamide (HMBA), undergo changes similar to the normal maturation of red blood cells (Friend et al., 1971; Reuben et al., 1976). These changes include alterations in morphology, sequential induction of enzymes in the haem biosynthetic pathway with the production of haem and haemoglobin, expression of carbonic anhydrase activity, and the appearance of spectrin and red blood cell surface antigens (Marks and Rifkind, 1978). It is anticipated that MELC will 
be a useful in vitro model to study drugitoxicant interactions during erythropoiesis.

In the studies described here we investigated the effects of lead on haem biosynthesis in MELC following HMBA-induced erythroid differentiation. The studies were designed to assess the ability of lead to (1) impair haem formation through a disruption in the normal maturation process and/or perturbation of selected enzymes in the haem biosynthetic pathway, and (2) to produce a state of erythroid hypoplasia in differentiating MELC).

\section{MATERIALS AND METHODS}

Cell culture. The murine erythroleukaemia cell line, clone $745 \mathrm{~A}$, derived from the $\mathrm{DBA} / 2$ mouse, was obtained from the NIGMS Human Genetic Mutant Cell Repository, Institute for Medical Research, (Camden, NJ, USA). Cells were seeded at a final density of $5 \times 10^{5}$ cells $/ \mathrm{ml}$ in spinner flasks. Spinner cultures were maintained in an incubator at $37^{\circ} \mathrm{C}$ in medium consisting of Iscove's modified Dulbecco's minimum essential medium (MEM); Boehringer Mannheim Biochemicals, Indianapolis, IN, USA) supplemented with $5 \%(\mathrm{v} / \mathrm{v})$ defined bovine calf serum (Hyclone Laboratories Inc., Logan, UT, USA). Induction of differentiation was achieved by addition of a stock solution $(250 \mathrm{mM})$ of HMBA (Sigma Chemical Co.. St Louis, MO. USA) to a final medium concentration of $3 \mathrm{~mm}$. To assess the effects of lead, MELC were induced to differentiate in the continuous presence of 0 (control), 20,40 or $80 \mu \mathrm{M}$ lead by appropriate freshly prepared dilutions in medium of a stock lead acetate solution in distilled deionized water $(10 \mathrm{~mm})$. Lead concentrations were chosen on the basis of solubility limits in culture medium and cell viability (trypan blue exclusion) during exposure periods. The actual lead concentrations in medium were $19.5,38.7$ and $77.2 \mu \mathrm{M}$ as determined by atomic absorption spectrophotometry (Chemical Pathology, Department of Pathology, Medical School, University of Michigan, MI, USA). The lead concentration in control medium was below the limits of detection. Under all conditions, cell viability was $>90 \%$. Cultures were split every other day to $5 \times 10^{5}$ cells $/ \mathrm{ml}$ by dilution in fresh MEM containing HMBA and lead where appropriate.

Unless stated otherwise, the following parameters were determined 2, 4 and 6 days after induction exposure as described below.

Cell density and benzidine staining. Cell density was carried out using a haemocytometer. Cell doubling time was measured according to the method described by Patterson (1979). The percentage of haemoglobin-containing cells was determined at 6 days by benzidine staining according to the method of Gopalakrishnan and Anderson (1979). A minimum of 500 cells were evaluated for each condition.

Haem content. Haem content was measured by the microfluorometric method of Sassa (1976). Briefly, cell pellets were rinsed in phosphate buffered saline (PBS; pH 7.45) and heated in 2 m-oxalic acid for $30 \mathrm{~min}$ at $100^{\circ} \mathrm{C}$. Hemin (Sigma Chemical Co.) served as a standard and was heated similarly. After cooling, fluorescence was determined on an Aminco-Bowman
Spectrophotofluorometer (American Instrument Co. Inc., Silver Spring, MD, USA).

Subcellular fractionation. At the indicated times, MELC were collected by centrifugation at $100 \mathrm{~g}$ for $10 \mathrm{~min}$ and rinsed with PBS. The washed cell pellets (from control and lead-exposed MELC) were weighed and resuspended in three volumes of ice-cold distilled deionized water to lyse cells. These suspensions were homogenized manually with 15 strokes in a glass-teflon homogenizer and then adjusted to $\mathrm{pH} 7.8$ by the addition of six volumes of $50 \mathrm{~mm}$-Tris$\mathrm{HCl}$ ( $\mathrm{pH} \mathrm{8.0)}$. The homogenate was centrifuged at $800 \mathrm{~g}$ for $15 \mathrm{~min}$ to remove cellular debris. The resulting supernatant was centrifuged at $9000 \mathrm{~g}$ for $20 \mathrm{~min}$, yielding a mitochondrial pellet. This mitochondrial pellet, washed and resuspended in $50 \mathrm{~mm}$ Tris- $\mathrm{HCl}$ ( $\mathrm{pH} \mathrm{7.4),} \mathrm{served} \mathrm{as} \mathrm{the} \mathrm{enzyme} \mathrm{source.} \mathrm{The}$ resulting $9000-g$ supernatant was centrifuged at $100,000 \mathrm{~g}$ for $60 \mathrm{~min}$ to form the cytosolic fraction and the microsomal pellet. The cytosolic fraction served as the enzyme source. Protein content was determined by the method of Lowry et al. (1951) using bovine serum albumin as standard.

Activities of haem biosynthetic enzymes. The activity of ALA-D was measured in MELC cytosol by the method of Gibson et al. (1955). The product, porphobilinogen (PBG), was measured spectrophotometrically $(553 \mathrm{~nm})$ after reaction with Ehrlich's reagent (Mauzerall and Granick, 1956). Spectrophotometric determination of PBG was carried out on an SLM Aminco DW-2000 UV-VIS Spectrophotometer (SLM Instruments Inc., Urbana, IL, USA) using a millimolar extinction coefficient of 61 .

Cytosolic uroporphyrinogen I synthetase (URO-S) was measured by a modification (Sassa et al., 1974) of the method of Strand et al. (1972). The cytosolic preparation was incubated with $100 \mu \mathrm{M}$-PBG (Porphyrin Products, Logan, UT, USA) in $50 \mathrm{~mm}$-Tris$\mathrm{HCl}-50 \mathrm{~mm}-\mathrm{KCl}(\mathrm{pH} 7.8)$ at $37 \mathrm{C}$ for $45 \mathrm{~min}$. The reaction was terminated by cooling tubes on ice and immediately adding ethyl acetate-acetic acid $(2: 1$, $\mathrm{v} / \mathrm{v}$ ). Then $1.0 \mathrm{~N}-\mathrm{HCl}$ was added and the mixture was shaken vigorously. The phases were allowed to separate and stand for $30 \mathrm{~min}$ in room light. The porphyrin fluorescence in the lower aqueous phase was determined and compared to a uroporphyrin I standard (Porphyrin Products) using a spectrophotofluorometer.

Mitochondrial FERRO activity was measured by the pyridine haemochromagen method described by Dailey (1986). The assay measures the formation of deuterohaem from deuteroporphyrin IX (Porphyrin Products). Deuterohaem was quantitated by reduced minus oxidized difference spectra of its pyridine haemochrome by UV-visible spectrophotometry. For deuterohaem, a millimolar extinction coefficient $(545-530 \mathrm{~nm})$ of 15.3 was used.

Microsomal haem oxygenase. Microsomal haem oxygenase activity was measured according to the method described by Tenhunen et al. (1968).

Uroporphyrin I and III isomer composition. The composition of uroporphyrin isomers formed in the URO-S assay was analysed by HPLC as described by Rideout et al. (1983). Separations were carried out on a Waters Associates (Model 6000A) solvent delivery system interfaced to a Schoeffel (Model FS 970) 
fluorometer equipped with a $\mathrm{Cl} 8$ bonded column (spherical $5 \mu \mathrm{m}, 4.6 \mathrm{~mm}$ diameter $\times 22 \mathrm{~cm}$ ) from Brownlee Labs (Santa Clara, CA, USA). The mobile phase was $13 \%(\mathrm{v} / \mathrm{v})$ acetonitrile in $1 \mathrm{M}$-ammonium acetate buffer ( $\mathrm{pH} 5.16)$.

DNA synthesis. DNA synthesis was measured as described by Friend et al. (1987). Cells were pulse labelled with [methyl ${ }^{3} \mathrm{H}$ ] thymidine $(0.5 \mu \mathrm{Ci} / \mathrm{ml} ;$ New England Nuclear, Boston, MA, USA) for $1 \mathrm{hr}$ at $37^{\circ} \mathrm{C}$ at 1,3 and $S$ days after induction/exposure $(\log$ phase growth). The incorporation of $\left.{ }^{3} \mathrm{H}\right]$ thymidine into the acid insoluble fraction of cells was determined by precipitation with 10\% trichloroacetic acid at $5^{\circ} \mathrm{C}$ and collection of precipitates on Whatman 3MM filter paper squares. Radioactivity was determined by liquid scintillation spectrometry.

Incorporation of $\left[{ }^{14} C\right] A L A$ into haem. Incorporation of ${ }^{14} \mathrm{C}$-labelled $\delta$-aminolaevulinic acid (ALA) into haem was measured by a modification of the method of Bonkowsky (1978). Cells were incubated with $\left[{ }^{14} \mathrm{C}\right] \mathrm{ALA}(0.17 \mu \mathrm{Ci} / \mathrm{ml}$; Amersham, Arlington Heights, IL, USA) for $24 \mathrm{hr}$ at $37^{\circ} \mathrm{C}$. Cell pellets $\left(8 \times 10^{6}\right.$ cells $)$ were reconstituted with ethyl acetateacetic acid $(4: 1, v / v$; ferrous sulphate washed) with $1 \mathrm{~mm}$-hemin (Sigma Chemical Co.) added as carrier, and extracted with distilled deionized water and $1 \mathrm{~N}-\mathrm{HCl} .{ }^{14} \mathrm{C}$ radioactivity in the dried ethyl acetate residue (haem phase) was determined in a Beckman LS8000 scintillation spectrometer using Scinti-Verse BD (Fisher Scientific, Fair Lawn, NJ, USA) as counting scintillant. The percentage recovery of carrier hemin was determined by the pyridine haemochromogen method (Falk, 1964) and found to be $>80 \%$ for both control and lead-treated cultures.

Statistics. Student's $t$-test was used to compare differences in mean values between control and leadexposed MELC cultures.

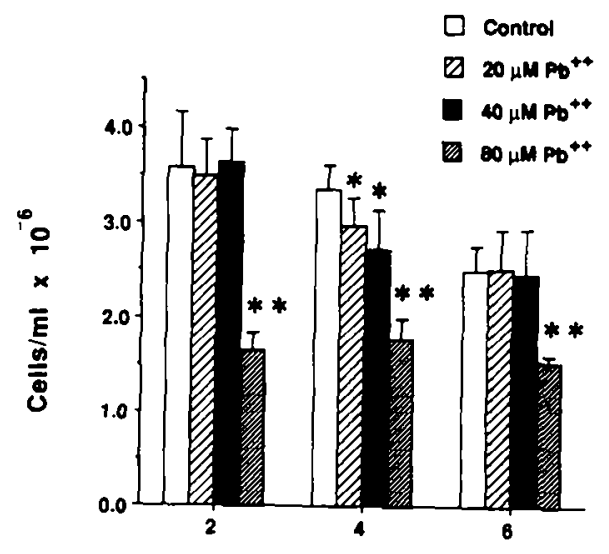

Day In Culture

Fig. 1. Effect of lead exposure on cell density in hexamethylene bisacetamide (HMBA)-induced cultures of murine erythroleukaemia cells (MELC). MELC were in-

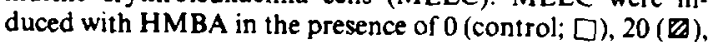
40 (D) or 80 (1) $\mu \mathrm{m}$-lead acetate. Cell density was determined at 2,4 and 6 days after induction/exposure. Each bar represents the mean $\pm S E M$ from twelve determinations. and asterisks denote a significant difference (Student's $t$-test) from the corresponding control value $(* P<0.01$; $* * P<0.001)$.

\section{RESULTS}

\section{Cell density and benzidine staining}

MELC cultures exposed to $80 \mu \mathrm{M}$-lead showed significant erythroid hypoplasia ( $40-50 \%$ decreases in cell density) at 2, 4 and 6 days after induction/ exposure (Fig. 1). Cells were also greatly enlarged in comparison with control MELC, with cell lysis evident (data not shown). Average cell doubling time was also significantly increased at this lead concentration for all three time periods $(18.36 \pm 2.02 \mathrm{hr}$ for controls $v \cdot 28.04 \pm 1.86 \mathrm{hr}$ for $80 \mu \mathrm{M}$-lead exposed, $P<0.0$ (). Cellular haemoglobin content was estimated by benzidine staining. Only MELC cultures exposed to $80 \mu \mathrm{M}$-lead showed a significant decrease ( $58 \%$ of control) in the percentage of benzidine positive cells at 6 days after induction/exposure $(84.3 \pm 2.4 \%$ for controls $v .48 .8 \pm 6.8 \%$ for $80 \mu \mathrm{M}$ lead exposed, $P<0.01$ ).

\section{Haem content}

There was a progressive accumulation of haemoglobin-associated haem in control MELC after HMBA induction (Fig. 2). Only MELC exposed to $80 \mu \mathrm{M}$-lead failed to show appreciable accumulation of haem over the 6-day period. In comparison with controls, there was a significant decrease in haem content in MELC exposed to $80 \mu \mathrm{M}$-lead at 2,4 and 6 days after induction/exposure and a slight but significant decrease in those exposed to $40 \mu \mathrm{M}$-lead at 6 days.

\section{DNA synthesis}

There was a significant decrease $(30-40 \%)$ in $\left[{ }^{3} \mathrm{H}\right]$ thymidine incorporation in MELC exposed to $80 \mu \mathrm{M}$-lead at 1,3 and 5 days after induction/ exposure (Table 1), consistent with the observed

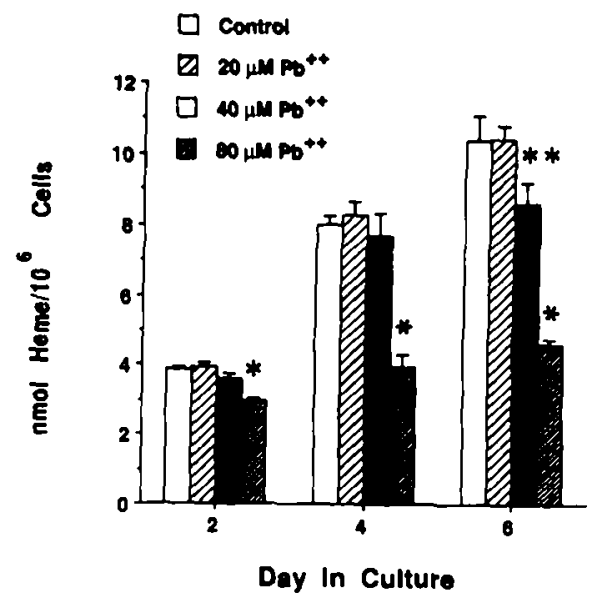

Fig. 2. Effect of lead exposure on haem content in hexamethylene bisacetamide-induced cultures of murine erythroleukaemia cells (MELC). MELC were induced with HMBA in the absence or presence of 0 (control, $\square$ ), 20 (B), 40 (D) or 80 (D) $\mu \mathrm{M}$-lead acetate. Haemoglobin-associated haem content was determined at 2,4 and 6 days after induction/ exposure. Each bar represents the mean \pm SEM from nine determinations and asterisks denote significant difference (Student's $t$-test) from the corresponding control value ( $P<0.01 ; * * P<0.001)$. 
Table I. Effect of lead exposure on [ $\left.{ }^{3} \mathrm{H}\right]$ thymidine incorporation into acid insoluble material in murine erythroleukaemia cells

\begin{tabular}{lccc}
\hline \multirow{2}{*}{$\begin{array}{l}\text { Lead } \\
\text { concn }(\mu \mathrm{M})\end{array}$} & \multicolumn{3}{c}{$\left.{ }^{3} \mathrm{H}\right]$ Thymidine incorporation $\left(\mathrm{cpm} / 10^{6}\right.$ cells) } \\
\cline { 2 - 4 } & Day 1 & Day 3 & Day 5 \\
\hline 0 (control) & $1190 \pm 25$ & $1150 \pm 171$ & $900 \pm 28$ \\
20 & $1148 \pm 57$ & $919 \pm 41$ & $735 \pm 17$ \\
40 & $1047 \pm 46$ & $895 \pm 31$ & $776 \pm 29$ \\
80 & $805 \pm 17^{*}$ & $690 \pm 11 *$ & $517 \pm 19^{\star}$ \\
\hline
\end{tabular}

Values are the means + SEM from three determinations, and those marked with an asterisk differ significantly (Student's 1 -test) from the corresponding control value $(* P<0.05)$.

perturbations in cell density (Fig. 1) and cell doubling time.

Activities of haem biosynthetic enzymes and composition of uroporphyrin isomers

Increases in the activities of the haem biosynthetic enzymes ALA-D, URO-S and FERRO were observed in control MELC following HMBA induction (Sassa, 1976), with maximum levels of activity attained at day 4 for ALA-D and URO-S and at day 6 for FERRO (Table 2). Following lead exposure, all three enzymes showed varying degrees of reduced activity in comparison with controls. A significant decrease $(30-40 \%)$ in ALA-D activity, by far the most sensitive index of lead exposure, was noted at 20 and $40 \mu \mathrm{M}$-lead and only $20-40 \%$ of control activity was observed for MELC exposed to $80 \mu \mathrm{m}$-lead. The profound inhibition in ALA-D activity noted at $80 \mu \mathrm{M}$-lead could be reversed by reactivation using zinc and dithiothreitol (DTT) in the assay incubation (Table 3) as reported by others (Finelli et al.. 1975; Geisse et al., 1983; Tzukamoto et al., 1979). URO-S activity was significantly depressed $(66 \%$ of control activity) only after exposure to $80 \mu \mathrm{M}$-lead and at 4 days after induction. MELC exposed to 40 or $80 \mu \mathrm{M}$ lead showed no significant differences from controls in the proportions of uroporphyrin I and III isomers formed in the URO-S assay (Fig. 3). A significant decrease (50-60\% of control activity) in FERRO was observed only in MELC exposed to $80 \mu \mathrm{M}$-lead.

Table 2. Effect of lead exposure on selected haem biosynthetic enzymes in murine erythroleukaemia cells

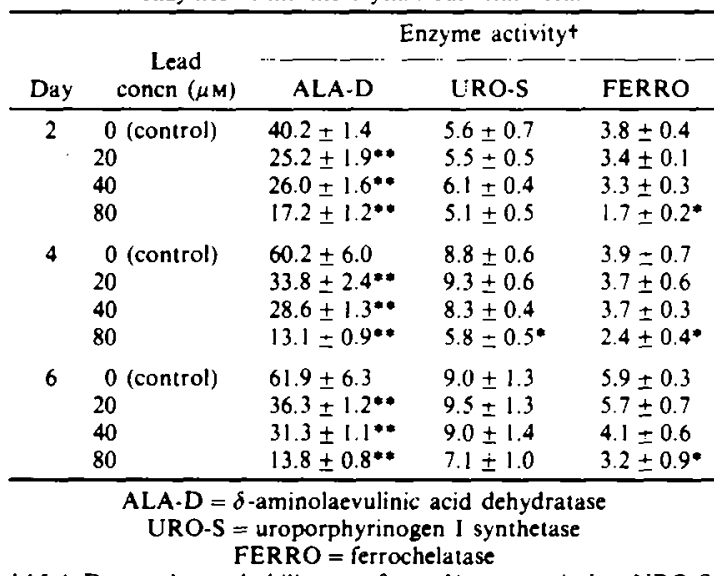

+ALA-D: nmol porphobilinogen formedimg proteinihr; URO-S: nmol uroporphyrinogen formed;mg protein $45 \mathrm{~min}$; FERRO: nmol deuterohaem formedimg protein $/ \mathrm{hr}$.

Values are means \pm SEM from three determinations and those marked with asterisks differ significantly (Student's $t$-test) from the corresponding control value $\left({ }^{\circ} P<0.05 ;{ }^{*} P<0.01\right)$.
Table 3. Reversal of lead inhibition of $\delta$ aminolaevulinic dehydratase activity by inclusion of dithiothreitol and zinc in the incubation

\begin{tabular}{|c|c|c|c|c|}
\hline \multirow[b]{2}{*}{$\begin{array}{c}\text { Lead } \\
\text { concn }(\mu M)\end{array}$} & \multicolumn{4}{|c|}{$\begin{array}{c}\text { ALA-D activity } \\
\text { (nmol PBG:mg protein/hr) }\end{array}$} \\
\hline & $\begin{array}{l}\text { Without } \\
\text { DTT!Zn }\end{array}$ & $\begin{array}{c}\% \\
\text { Control }\end{array}$ & $\begin{array}{c}\text { With } \\
\text { DTT }: \mathrm{Zn}^{2+}\end{array}$ & $\begin{array}{c}\% \\
\text { Control }\end{array}$ \\
\hline 0 (control) & $39.7 \pm 1.8$ & - & $38.5 \pm 0.8$ & - \\
\hline 80 & $12.2 \pm 0.4^{*}$ & 31 & $45.6 \pm 0.4^{\circ}$ & 118 \\
\hline
\end{tabular}

ALA-D $=\delta$-aminolaevulinic acid dehydratase

DTT $=$ dithiothreitol $\quad$ PBG $=$ porphobilinogen

DTT and $\mathrm{ZnCl}_{2}$ were added at concentrations of 16 and $0.1 \mathrm{mM}$. respectively.

Values are means \pm SEM for three determinations and those marked with asterisks differ significantly (Student's $t$-test) from the control value $(* P<0.001)$.

\section{Microsomal haem oxygenase}

The activity of microsomal haem oxygenase was found to be non-detectable and non-inducible by lead exposure in MELC (data not shown).

\section{Incorporation of $\left[{ }^{14} C\right] A L A$ into haem}

The effect of lead exposure on haem synthesis was investigated by measurement of $\left[{ }^{14} \mathrm{C}\right] \mathrm{ALA}$ incorporation into haem. Maximum levels of $\left[{ }^{14} \mathrm{C}\right] \mathrm{ALA}$ incorporation into haem were observed in control MELC between day 3 and day 5 after HMBA induction (Fig. 4). MELC exposed to $80 \mu \mathrm{M}$-lead showed significant decreases $(50 \%)$ in $\left[{ }^{14} \mathrm{C}\right] \mathrm{ALA}$ incorporation during this time period. These results were consistent
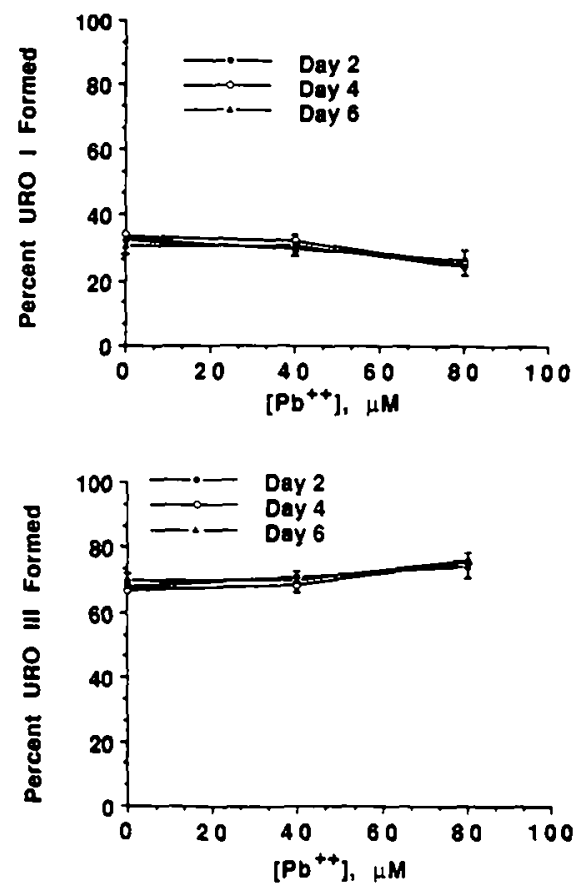

Fig. 3. Effect of lead exposure on the isomeric composition of uroporphyrinogen formed in hexamethylene bisacetamideinduced cultures of murine erythroleukaemia cells (MELC). MELC were induced with HMBA in the absence or presence of lead acetate. The proportions of uroporphyrin isomers I and III formed in the uroporphyrinogen I synthetase assay at $2(O), 4(O)$ and $6(\Delta)$ days after induction/exposure were determined by HPLC. Values represent the percentages of uroporphyrin I and III formed \pm SEM from six determinations. 


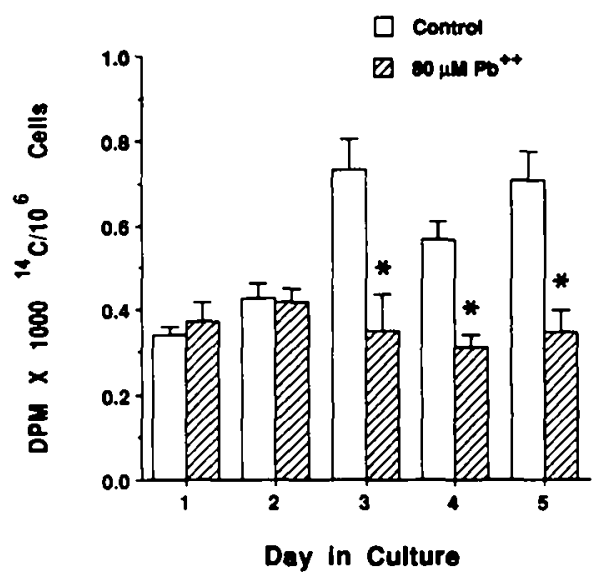

Fig. 4. Effect of lead exposure on the incorporation of ${ }^{14} \mathrm{C}$-labelled $\delta$-aminolaevulinic acid $\left(\left[{ }^{14} \mathrm{C}\right] \mathrm{ALA}\right)$ into haem in hexamethylene bisacetamide-induced cultures of murine erythroleukaemia cells (MELC). MELC were induced with HMBA in the absence ( $\square$ ) or presence of lead acetate $(80 \mu \mathrm{M} ; \mathrm{C})$. The incorporation of $\left[{ }^{14} \mathrm{C}\right] \mathrm{ALA}$ into haem at 24-hr intervals between day $\mathrm{I}$ and day 5 was measured as described in Materials and Methods. Values represent the mean incorporation \pm SEM from four determinations, and an asterisk denotes a significant difference (Student's $t$-test)

from the corresponding control value $\left({ }^{*} P<0.001\right)$.

with the lack of appreciable haem accumulation noted for this lead concentration (Fig. 2).

\section{Discussion}

Previous studies of erythropoiesis using bone marrow cells in vitro have been complicated by the contamination of the erythroid cellular component with myeloid and stromal elements and the lack of adequate control over the maturation program of erythroid precursors (Allen and Dexter, 1983; Dexter, 1979). MELC are a clonal cell line of erythroid precursors whose maturation program can be controlled by the addition of soluble polar chemicals such as dimethylsulphoxide or HMBA (Marks and Rifkind, 1978) and we have used them to study the effects of lead on erythroid cell growth and maturation and the synthesis of haem.

The results showed a significant decrease in the accumulation of haemoglobin-associated haem only in MELC exposed to $80 \mu \mathrm{M}$-lead following induction of differentiation with HMBA. However, this decrease in haem content was accompanied by cell enlargement, cell lysis and significant erythroid hypoplasia, with subsequent disruptions in DNA synthesis and cell doubling time. The data demonstrated that the impairment by lead of haem formation in MELC was coincident with the production of a severe erythroid hypoplasia with haemolytic changes.

With respect to cases of human lead exposure, it is rather difficult to assess the relationship between the concentration of lead required to impair haem synthesis in this in vitro system with that which might be attainable in humans, by either general or occupational exposure, because most of the data for humans are expressed in terms of lead concentration in blood $(\mathrm{BPb})$, not in bone marrow, although bone marrow is the major site of haem synthesis. It has been estimated that the concentration of lead in bone and marrow is 50-80 times that in the blood (Albahary, 1972; Baloh, 1974; Flood et al., 1988; Gross et al., 1975), with normal $\mathrm{BPb}$ levels ranging between 20 and $40 \mu \mathrm{g} / 100 \mathrm{ml}$. However, a subsequent long-term survey has revealed that $\mathrm{BPb}$ levels in US adults have been declining to a value of around $10 \mu \mathrm{g} / 100 \mathrm{ml}$ (Annest, 1983). In cases of occupational lead poisoning, $\mathrm{BPb}$ values may exceed $80 \mu \mathrm{g} / 100 \mathrm{ml}$ (Brangstrup Hansen et al., 1981). Lead in bone and marrow is distributed among the cellular components (erythroid precursors, myelocytes, granulocytes) as well as the mineralized bone matrix itself. Recent studies using laser microbeam mass analysis to assess lead distribution on the subcellular level suggest that lead is three to ten times more concentrated in nuclei than in the cytoplasm of bone marrow cells (Flood $e t$ al., 1988). Using the data obtained from an individual with severe lead poisoning, a crude estimation of the concentration of lead in the cytoplasm of all bone marrow cell types lies between 20 and $60 \mu \mathrm{M}$. Unfortunately, Ca-EDTA chelation therapy had commenced in this individual before the measurements were taken. In the in vitro system described here, only the erythroid cellular component of marrow was exposed to lead. Thus, until further data become available, it remains uncertain whether the erythroid element of bone marrow in vivo would be exposed to the concentration of lead that was required to impair haem synthesis in this in vitro system.

The effect of lead exposure on haem formation in MELC was determined by evaluating the activities of selected enzymes in the haem synthetic pathway and the incorporation of $\left[{ }^{14} \mathrm{C}\right] \mathrm{ALA}$ into haem. In the haem synthetic pathway, the activity of ALA-D was most sensitive to lead, followed by FERRO and URO-S, respectively, with the latter two showing significant decreases only at $80 \mu \mathrm{M}$-lead. A significant depression in the activity of ALA-D has been reported in rat whole bone marrow cell suspensions with exposure to as low as $0.5 \mu \mathrm{M}$-lead (Dresner $e t$ al., 1982). However, it is difficult to compare their results with ours because of the differences both in lead exposure conditions and methods of cell culture. No effect of lead exposure was noted in the proportion of uroporphyrinogen I and III isomers formed in the URO-S assay. Levels of haem were depressed only under conditions in which the activities of all three enzymes studied were decreased. Furthermore, decreases in the activity of ALA-D of up to $50 \%$ could occur without any significant decrease in haem content. This observation is analogous to that in humans. ALA-D activity is negatively correlated with $\mathrm{BPb}$ concentration in the general population (Lolin and O'Gorman, 1986; Secchi and Alessio, 1974; Waldron, 1974), and is impaired by $\mathrm{BPb}$ levels well within the range of values found in individuals with only environmental exposure. It is believed that since the reserve capacity of ALA-D is large, its inhibition at low $\mathrm{BPb}$ levels is not likely to interfere with haem synthesis (Waldron, 1974).

It has been suggested that lead's effect on haem synthesis most probably involves interference with a number of enzymes in the haem synthetic pathway. In humans, decreases in erythrocyte URO-S are not often observed in lead poisoning (Campbell et al., 
1977; El-Waseef, 1982), although lead-associated decreases are observed when 5-aminolaevulinic acid is used as substrate rather than porphobilinogen (El-Waseef, 1982; Ford et al., 1980), suggesting that substrate deprivation through inhibition of ALA-D plays a role in impairing subsequent synthesis of uroporphyrinogen. Using porphobilinogen as substrate, URO-S showed the least extent of inhibition by lead in the in vitro system described here, with no effect on the composition of uroporphyrinogen isomers formed. The relative lack of sensitivity of uroporphyrinogen synthesis to lead inhibition may be explained by the fact that, in this system as well as in liver, this step is well protected by a low-molecularweight, heat-stable factor (Ku and Piper, 1990; Piper and van Lier, 1977).

The activity of FERRO was significantly affected by the highest concentration of lead used in our in vitro system. In lead poisoning in humans, profound depression in the activity of FERRO, measured by either the percentage of ${ }^{59} \mathrm{Fe}$ uptake into haem or the level of erythrocyte protoporphyrin, has been observed (Campbell et al., 1977; Lubran, 1980; Piomelli et al. 1982; Rogan et al., 1986). As for other enzymes in the haem synthetic pathway, Campbell et al. (1977) reported marked elevation of ALA synthase, normal uroporphyrinogen decarboxylase and depressed coproporphyrinogen oxidase as common features of lead poisoning in addition to the enzyme changes previously mentioned. In our in vitro system, the activities of these enzymes were not determined.

The question may be raised as to whether increases in haem catabolism could explain the decrease in haem content at $80 \mu \mathrm{M}$-lead. However, haem oxygenase activity was found to be extremely low and non-inducible by lead exposure in MELC. Furthermore, a lead-associated disruption in the ability to synthesize haem was confirmed by the decreased incorporation of $\left[{ }^{14} \mathrm{C}\right] \mathrm{ALA}$ into haem that was noted in MELC exposed to $80 \mu \mathrm{M}$-lead.

Overall, the data are consistent with the suggestion that a lead-associated disruption in haem synthesis involves interference with a number of enzymes in the haem synthetic pathway, and that this disruption is accompanied and complicated by severe erythroid hypoplasia. Apart from the question of the lead concentrations used, the in vitro system described here provides a useful model to study the regulation of haem synthesis, isomer composition of haem intermediates, and drug/toxicant interactions during erythropoiesis. Furthermore, by manipulation of the tissue culture environment, it is possible to identify the role of various hormonal and nutritional factors that regulate haem synthesis and/or influence the development of lead- or drug-associated anaemia. In our laboratory, a major interest is the role of polyglutamated folate derivatives that protect against inhibition of URO-S by lead (Ku and Piper, 1990; Piper and van Lier, 1977). Most importantly, the use of the MELC technique to evaluate the potential of commercial and or therapeutic products to impair haem formation and/or interfere with normal erythroid development should refine conditions to study the basic underlying mechanism of action in the absence of complicating factors encountered in tivo.
Acknowledgements - This investigation was supported by grants ES-02424 and ES-07062. The authors thank Elise Fader for assistance in the typing of this manuscript.

\section{REFERENCES}

Albahary C. (1972) Lead and hemopoiesis. The mechanisms and consequences of the erythropathy of occupational lead poisoning. Am. J. Med. 52, 367-378.

Allen T. D. and Dexter T. M. (1983) Long term marrow cultures: an ultrastructural review. Scanning Elect. Microsc. (Pt. 4), 1851-1866.

Annest J. L. (1983) Trends in the blood lead levels of the US population-NHANES II 1976-1980. In Lead Versus Health. Edited by M. Rutter and R. R. Jones. pp. 33-58. John Wiley \& Sons, New York.

Baloh R. W. (1974) Laboratory diagnosis of increased lead absorption. Archs envir. Hith 23, 198-208.

Bonkowsky H. L., Bement W. J. and Erny R. (1978) A rapid, simple method for obtaining radiochemically pure hepatic heme. Biochim. biophys. Acta 541, 119-123.

Bottomley S. S. (1977) Porphyrin and iron metabolism in sideroblastic anemia. Semin. Hematol. 14, 169-185.

Bottomley S. S. and Muller-Eberhard U. (1988) Pathophysiology of heme synthesis. Semin. Hematol. 25, 282-302.

Brangstrup Hansen J. P., Dossing M. and Paulev P.-E. (1981) Chelatable lead body burden (by calcium disodium EDTA) and blood lead concentration in man. $J$. occup. Med. 23, 39-43.

Campbell B. C., Brodie M. J., Thompson G. G., Meredith P. A., Moore M. R. and Goldberg A. (1977) Alterations in the activity of enzymes of haem biosynthesis in lead poisoning and acute hepatic porphyria. Clin. Sci. molec. Med. 53, 335-340.

Dailey H. A. (1986) Purification and characterization of bacterial ferrochelatase. Meth. Enzymol. 123, 408-415.

Dexter T. M. (1979) Haemopoiesis in long-term bone marrow cultures. A review. Acta Haemat. (Basel) 62 , 299-305.

Dresner D. L., Ibrahim N. G., Mascarenhas B. R. and Levere R. D. (1982) Modulation of bone marrow heme and protein synthesis by trace elements. Entir. Res. 28, $55-66$.

El-Waseef A. (1982) Uroporphyrinogen-I-synthetase activity in red blood cells of lead-exposeci workers. Acta med. hung. 39, 95-100.

Falk J. E. (1964) Haems. In Porphyrins and Metalloporphyrins. Vol. 2. Edited by J. E. Falk. pp. 181-189. Elsevier, New York.

Finelli V. N., Klauder D. S., Karaffa M. A. and Petering H. G. (1975) Interaction of zinc and lead on deltaaminolevulinate dehydratase. Biochem. biophys. Res. Commun. 65, 303-311.

Flood P. R., Schmidt P. F., Wesenberg G. R. and Gadeholt H. (1988) Distribution of lead in human hemopoietic tissue and spongy bone after lead poisoning and $\mathrm{Ca}$ EDTA chelation therapy. Archs Toxicol. 62, 295-300.

Ford R. E., Ou C.-N. and Ellefson R. D. (1980) Assay for erythrocyte uroporphyrinogen I synthetase activity, with porphobilinogen as substrate. Clin. Chem. 26, 1182-1185.

Friend C., Scher W., Holland J. G. and Sato T. (1971) Hemoglobin synthesis in murine virus induced leukemic cells in vitro: stimulation of erythroid differentiation by dimethyl sulfoxide. Proc. nain. Acad. Sci. U.S.A. 68, 378-382.

Friend C., Zajac-Kaye M., Holland J. G. and G.-T. Pogo B. (1987) Depletion of sodium butyrate from the culture medium of friend erythroleukemia cells undergoing differentiation. Cancer Res. 47, 378-382.

Geisse S.. Bruller H.-J. and Doss M. (1983) Porphobilinogen synthase (delta-aminolevulinic acid dehydratase) activity in human erythrocytes: reactivation by zinc and 
dithiothreitol depending on influence of storage. Clinica chim. Acta 135, 239-245.

Gibson K. D., Neuberger A. and Scott J. J. (1955) The purification and properties of delta-aminolevulinic acid dehydrase. Biochem. J. 61, 618-629.

Gopalakrishnan T. V. and Anderson W. F. (1979) Mouse erythroleukemia cells. Meth. Enzymol. 58, 506-511.

Gross S. B., Pfitzer E. A., Yeager D. W. and Kehoe R. A. (1975) Lead in human tissues. Toxic. appl. Pharmac. 32, 638-651.

Ku W. W. and Piper W. N. (1990) Pteridine modulation of lead inhibition of uroporphyrinogen synthesis in erythroid precursor cells. Toxicology Lett. 51, 91-97.

Lolin Y. and O'Gorman P. (1986) delta-Aminolevulinic acid dehydratase as an index of the presence and severity of lead poisoning in acute and chronic lead exposure. Ann. clin. Biochem. 23, 521-528.

Lowry O. H., Rosebrough N. J., Farr A. L. and Randall R. J. (1951) Protein measurement with the Folin phenol reagent. J. biol. Chem. 193, 265-275.

Lubran M. M. (1980) Lead toxicity and heme biosynthesis. Ann. clin. lab. Sci. 10, 402-413.

Marks P. A. and Rifkind R. A. (1978) Erythroleukemic differentiation. A. Rev. Biochem. 47, 419-448.

Mauzerall D. and Granick S. (1956) The occurrence and determination of delta-aminolevulinic acid and porphobilinogen in urine. J. biol. Chem. 219, 435-446.

Patterson M. K., Jr (1979) Measurement of growth and viability of cells in culture. Meth. Enzymol. 58, 141-152.

Piomelli S., Seaman C., Zullow D., Curran A. and Davidow B. (1982) Threshold for lead damage to heme biosynthesis in urban children. Proc. natn. Acad. Sci. U.S.A. 79, 3335-3339.

Piper W. N. and van Lier R. B. L. (1977) Pteridine regulation of inhibition of hepatic uroporphyrinogen synthetase activity by lead chloride. Molec. Pharmac. 13, 1126-1135.

Reuben R. C., Wife R. L., Breslow R., Rifkind R. A. and Marks P. A. (1976) A new group of potent inducers of differentiation in murine erythroleukemia cells. Proc. natn. Acad. Sci. U.S.A. 73, 862-866.

Rideout J. M., Wright D. J. and Lim C. K. (1983) High pressure liquid chromatography of uroporphyrin isomers. J. Liq. Chromat. 612, 383-394.

Rogan W. J., Reigart J. R. and Gladen B. C. (1986) Association of aminolevulinate dehydratase levels and ferrochelatase inhibition in childhood lead exposure. J. Pediat. 109, 60-64.

Sassa S. (1976) Sequential induction of heme pathway enzymes during erythroid differentiation of mouse friend leukemia virus-infected cells. J. exp. Med. 143, 305-315.

Sassa S. (1978) Toxic effects of lead, with particular reference to porphyrin and heme metabolism. In Heme and Hemoproteins. Edited by F. DeMatteis and W. N. Aldridge. pp. 333-371. Springer-Verlag, New York.

Sassa S., Granick S., Bickers D. R., Bradlow H. L. and Kappas A. (1974) A microassay for uroporphyrinogen I synthetase, one of three abnormal enzyme activities in acute intermittent porphyria, and its application to the study of the genetics of this disease. Proc. natn. Acad. Sci. U.S.A. 71, 732-736.

Secchi G. C. and Alessio L. (1974) Laboratory results of some biological measures in workers exposed to lead. Archs envir. Hith 29, 351-354.

Strand L. J., Meyer U. A., Felsher B. F., Redeker A. G. and Marver H. S. (1972) Decreased red cell uroporphyrinogen I synthase activity in intermittent acute porphyria. J. clin. Invest. 51, 2530-2536.

Tenhunen R., Marver H. S. and Schmid R. (1968) The enzymatic conversion of heme to bilirubin by microsomal heme oxygenase. Proc. natn. Acad. Sci. L.S.A. 61, 748-755.

Tzukamoto I., Yoshinaga T. and Sano S. (1979) The role of zinc with special reference to the essential thiol groups in delta-aminolevulinic acid dehydratase of bovine liver. Biochim. biophys. Acta 570, 167-178.

Waldron H. A. (1974) The blood lead threshold. Archs entir. Hlih 29, 271-273. 